\title{
GRITOS SEM PALAVRAS: RESISTÊNCIAS DAS CRIANC̣AS PEQUENININHAS NEGRAS FRENTE AO RACISMO
}

Flávio Santiago*

Universidade Zumbi dos Palmares (UNIPALMARES)

RESUMO: O presente artigo tem como objetivo compreender a partir dos pressupostos teóricos da Sociologia da Infância e dos estudos das Ciências Sociais, relacionados às relações raciais no Brasil, a violência do processo de racialização sobre a construção das culturas infantis. Trata-se de uma pesquisa com uma abordagem etnográfica realizada com crianças pequenininhas de três anos, em um Centro de Educação Infantil da região metropolitana de Campinas. Os resultados apontam que na instituição investigada existem uma reprodução dos preconceitos referentes à categoria racial e a legitimação das hierarquizações sociais que legitimam as desigualdades. Indicam, também, como as crianças pequenininhas negras percebem o racismo presente nas posturas pedagógicas adotadas pelos(as) docentes e deixam explícita, por meio de diferentes linguagens, a não aceitação dos enquadramentos que as fixam em posições subalternas na sociedade.

Palavras-chave: Racismo. Crianças pequenininhas negras. Educação infantil. Culturas infantis.

http://dx.doi.org/10.1590/0102-4698132765

* Doutorando no Programa de Pós-Graduação em Educação da Universidade Estadual de Campinas (UNICAMP). Membro do Grupo de Estudos e Pesquisas em Educação e Diferenciação Sociocultural da UNICAMP. Professor da Faculdade Zumbi dos Palmares (UNIPALMARES). E-mail: flavio.fravinho@gmail.com 
SCREAMS WITHOUT WORDS: BLACK YOUNG CHILDREN'SRESISTANCE CONFRONTING RACISM

ABSTRACT: The present article aims to understand, from the theoretical assumptions of Childhood Sociology, and studies of Social Sciences connected to racial relations in Brazil, the violence of the process of racialization over the construction of peer cultures. It is a research with an ethnographic approach carried out with three-year-old tiny young children in an Early Childhood Center at the metropolitan region of Campinas. The results point out that for the investigated institution, there is a reproduction of prejudices related to the racial category and to the legitimacy of social hierarchies that legitimize the inequalities. The results also indicate how the tiny young black children perceive the racism present on the pedagogies adopted by the teachers, and make it explicit, by means of different languages, the non-acceptance of the frameworks that pin them down in subordinate positions in the society.

Keywords: Racism. Black young children. Early childhood education. Peer cultures.

\section{INTRODUCุÃO}

A pesquisa que originou o presente artigo caracteriza-se como uma pesquisa de abordagem etnográfica, compreendida como movimento de encontros, que permitiu o convívio, a escuta e a aprendizagem constante das relações que estruturam o campo de investigação, possibilitando um desenraizamento de pré-concepções de sujeito, sociedade e relações sociais.

O movimento etnográfico da pesquisa que resultou neste artigo foi sendo construído no entrelaçamento da minha subjetividade com as dos sujeitos presentes no campo de pesquisa, promovendo a construção de encontros que possibilitavam ouvir pacientemente todos os sons e enxergar todas as cores presentes nas relações que os sujeitos estabeleciam no campo, bem como perceber todos os cheiros.

Ao me permitir embarcar no movimento potencializado pela etnografia, o meu olhar e a minha escuta foram afetados pelos diferentes elementos do campo, proporcionando a construção do meu próprio navegar, fundado na minha sensibilidade e na minha permissividade ao novo. Para a construção efetiva desse movimento, foi necessária a aceitação de participação de todos os sujeitos envolvidos na pesquisa, não de um modo burocrático, através de autorizações e termos de consentimentos, mas através de olhares, gestos e palavras que demonstravam a possibilidade de aproximação e penetração no mundo de cada um deles, e, a partir daí, de conhecer as facetas da realidade sociocultural que os produziram e construíram as estruturas sociais que os amarram. 
O espaço escolhido para a realização do campo empírico foi um Centro de Educação Infantil da região metropolitana de Campinas. A opção pela realização da pesquisa nesse espaço deu-se em função de ser pertencente à rede pública e estar situado em um bairro com uma historicidade marcada pela segregação racial. A pesquisa envolveu crianças pequenininhas ${ }^{1}$ de três anos e suas/seus docentes.

A minha relação com o campo de pesquisa foi estabelecida por meio da observação, pela qual procurei aguçar o meu olhar para as linguagens que, por vezes, são pouco evidenciadas por outras pesquisas acadêmicas. Também registrei, em um diário de campo, as minhas impressões sobre cenas ocorridas, descrevendo detalhadamente aquilo que mais me chamava atenção.

As observações foram realizadas da seguinte maneira: eu chegava ao Centro de Educação Infantil no início do período da tarde, às doze horas, e permanecia na sala até às dezoito horas. Anotava tudo o que conseguia escutar e observar: as falas dos/das docentes, as conversas, os silêncios e as vozes das crianças pequenininhas e as eventuais ocorrências durante o dia. As idas a campo foram realizadas de duas a três vezes por semana, entre os meses de agosto e dezembro de 2012.

Faz-se necessário salientar que os dados coletados durante a realização da pesquisa são resultado da intersecção de diferentes universos, entre eles, o do pesquisador e o do campo de pesquisa. O universo do Centro de Educação Infantil pesquisado era bastante diverso, havendo diferentes formas de atuação, negociação, ação, variação que não se restringiam apenas aos locais em que ocorriam, mas que abrangiam as percepções e identidades de tais lugares, de modo que o Centro de educação infantil não deve ser encarado como um todo homogêneo, mas a particularidade de cada caso deve ser pensada a fim de se aprofundar a análise (FONSECA, 1999). A aproximação com o campo também impunha determinados limites com base nas redes de significação já presentes no seu interior - em alguns momentos o estranho era eu, o "pesquisador", pois a minha chegada também representava um movimento de mudança dentro daquele ambiente já constituído.

Como salienta Velho (1978, p. 39), "o que sempre vemos e encontramos pode ser familiar mas não é necessariamente conhecido, e o que não vemos e encontramos pode ser exótico mas, até certo ponto conhecido". Acho importante tornar clara essa distinção entre familiar e conhecido, pois percebo que as idas ao Centro de Educação Infantil, algumas vezes, pareciam parte da minha rotina, algo familiar, no entanto, o meu olhar para as relações que ocorriam 
dentro da instituição não poderia deixar de atentar-se ao meu objetivo de investigação, o qual era compreender, a partir dos pressupostos teóricos da Sociologia da Infância e dos estudos das Ciências Sociais, relacionados às relações raciais no Brasil, a violência do processo de racialização sobre a construção das culturas infantis.

O conceito de racialização aqui adotado refere-se ao processo político e ideológico por meio do qual certas populações são identificadas por referência direta ou indireta às suas características fenotípicas reais ou imaginárias, de modo a sugerir que essa população só possa ser compreendida como uma suposta unidade biológica. Tal processo envolve a utilização direta da ideia de "raça" para descrever ou referir-se à população em questão (CASHMORE, 2000).

As pesquisas sobre as relações raciais que abordam a criança negra no espaço institucional da educação infantil (TRINIDAD, 2011; SOUZA, 2002; OLIVEIRA, 2004; CAVALLEIRO, 2003) apontam a racialização como um dos elementos mediadores das relações sociais estabelecidas entre as próprias crianças e entre os/as docentes e as crianças. Por meio desse processo, são construídas hierarquizações sociais, bem como desapropriações dos pertencimentos étnico-raciais dos meninos pequenininhos negros e das meninas pequenininhas negras.

As construções racistas presentes nas inúmeras experiências vivenciadas pela população negra impõem uma vivência cotidiana de não pertencimento social e de segregação racial, expondo as fragilidades do discurso igualitário existente no âmbito universalista homogeneizador, que demonstram como o racismo posiciona alguns sujeitos em um locus social de superioridade e outros em um locus social de inferioridade (SILVÉRIO et al, 2010).

Esse processo, como argumenta Bhabha (2007), faz parte do mecanismo de "introjeção" do discurso colonizador nas subjetividades dos sujeitos, criando imagens positivas das relações de exploração presentes nas hierarquias capitalistas e construindo corpos: invólucros de músculos, gorduras e ossos que passam a assumir adornamentos sociais com a finalidade de construção do indivíduo moderno, com uma nacionalidade, um gênero, uma sexualidade, uma raça e uma única cultura.

As crianças pequenininhas, conforme a pesquisa realizada nos evidencia, não são passivas nesses processos, resistindo e revolucionando as diferentes imposições normativas para a construção de suas vidas, criando novos modelos de existência e modificando a todo o momento os diferentes meios que as inventam. Essa forma de percepção das crianças pequenininhas nos possibilita pensar os 
meninos e as meninas para além de "seres em desenvolvimento, ou até mesmo, a partir dessa condição, com o objetivo de conhecê-las nas múltiplas relações que estabelecem nas experiências cotidianas, de onde retiramos os conteúdos presentes nas brincadeiras e interações" (NASCIMENTO, 2011, p.51).

Para Gombrowicz (2005) as crianças são a potencialidade do múltiplo, de uma produtividade sem mediação, a afirmação do ainda não previsto, não nomeado, não existente; a asseveração de que não há nenhum caminho predeterminado que uma criança (ou um adulto) deva seguir; de que não há nenhuma coisa que ela deva se tornar: a infância é "apenas" um exercício imanente de forças.

Nesse sentido, as crianças não são passivas, mas, sim, sujeitos concretos produtores de culturas infantis. Por meio da experiência direta e concreta, elas aprendem a "como agir em cada circunstância, na qualidade de parceir[as] e membro[s] de dado agrupamento social há um tempo" (FERNANDES, 2004, p. 207).

As crianças são sujeitos ativos, atuando diretamente nas relações sociais, contribuindo para construção do mundo e estabelecendo conexões diretas entre os diferentes sujeitos, adultos ou não adultos, que as rodeiam, produzindo culturas e ressignificando signos sociais. Esta forma de conceituação dos meninos pequenininhos e das meninas pequenininhas possibilita olharmos as produções socioculturais das crianças de modo a perceber, conforme afirma Faria (2005), que elas são capazes de estabelecer múltiplas relações e reconhecem seu pertencimento a determinada classe, gênero, sexualidade, etnia e raça - são meninos, meninas, negras, brancas, indígenas, mas, independentemente, são criaturas e criadoras da história e da cultura.

O conceito de cultura infantil que fundamenta este artigo tem como pressupostos os estudos pioneiros de Florestan Fernandes ([1943] 2004) realizados no bairro do Bom Retiro em São Paulo. Em seus trabalhos, o autor concebe a cultura infantil como o conjunto de relações em que as crianças têm possibilidades de manter contatos pessoais e de interagir socialmente com outras pessoas, desenvolvendo rotinas, artefatos, valores e interesses que possibilitam a incorporação de normas e padrões de comportamento em suas personalidades.

Como apresenta Prado (1999, p. 114) "as crianças apropriavamse dos espaços, dos objetos de formas diversificadas, nem sempre dentro do que era esperado pelos adultos - o que mostrava que elas não estavam submetidas somente a este referencial, mas inovavam a partir dele". Desse modo, por intermédio da relação com o outro, as crianças constroem as culturas infantis, uma rede de significados com características especificas e, portanto, expressões culturais específicas. 
Uma característica importante a ser destacada é que as culturas infantis não são independentes das culturas adultas, das relações de poder, das opressões e das desigualdades presentes na sociedade. Assim, o racismo, a opressão de classe, a homofobia, o machismo, também podem estar presentes nas inúmeras relações produzidas pelas crianças.

É importante destacar que não existe algo mágico, místico ou mesmo divino nas falas e culturas infantis; as crianças não estão em um mundo descolado do universo adulto, elas vivenciam as realidades construídas para legitimar todas as desigualdades presentes na sociedade. O que encontramos de novo nesse movimento é que, ao pensarmos nas crianças como protagonistas, existe uma inversão hierárquica que dá o direito à voz àquelas cujas falas não são levadas em conta (ABRAMOWICZ, 2011).

Reconhecer e assumir a criança como ser social que constrói e cria cultura não significa defender ou lutar pelo primado da criança em oposição ao do adulto. As relações que se estabelecem entre eles não se dão apenas como um jogo de espelhos ou reflexos alternantes. (PRADO, 1999, p. 116)

Por meio desse referencial, podemos visualizar as crianças como atores sociais que atuam diretamente nas relações sociais, contribuindo para a construção do mundo e estabelecendo conexões diretas entre os diferentes sujeitos, adultos ou não, que as rodeiam (BARBOSA, 2007).

Ao encontro dessa percepção de crianças, Corsaro (2011) propõe a noção de "reprodução interpretativa" como uma alternativa para compreensão dessa inserção ativa das crianças no mundo. Para ele, o termo reprodução enfatiza o quanto as crianças são frequentemente constrangidas pela estrutura social das diversas instituições culturais, sociais e políticas ao longo da vida para ficarem homogeneizadas e semelhantes ao padrão. Entretanto, com a palavra interpretativa, o autor salienta que as crianças não apenas internalizam a cultura, mas também contribuem ativamente para a mudança cultural.

Para Abramowicz e Levcovitz (2005), Scherer (2009) e Gallo (2010), no âmago desse processo, existem uma dissolução da criança "encarcerada, imobilizada e fechada" sob os olhares dos adultos colonizadores (olhar de vigilância) e uma transformação de perspectivas, desconstruindo a lógica "adultocêntrica", para a invenção de movimentos que buscam olhar a criança, enxergando a processualidade singular dos sujeitos crianças e de suas produções culturais.

Os gestos, os movimentos, as brincadeiras, as falas das crianças revelam, além de sistemas de aquisição de elementos 
simbólicos, também outras produções culturais construídas dentro do grupo com outras crianças e nas relações com os adultos. Esse movimento nos conduz a pensar que as crianças também são sujeitos que fazem história e que constroem cultura em condições dadas pela sociedade a que pertencem.

\section{EDUCAÇ̃̃O INFANTIL: DIFERENÇAS, RACISMOE CULTURAS INFANTIS EM MOVIMENTO}

Desde a década de 1970, avança a produção de pesquisas nos espaços de educação infantil, para demonstrar que o cuidado e a educação destinados às crianças eram desiguais e que parte dessas desigualdades relacionava-se ao seu pertencimento racial, ou seja, existia uma pedagogia da educação infantil racista (CUNHA JUNIOR et al, 1979; ROSEMBERG, 1980; OLIVEIRA, 1992; SOUZA, 2002; OLIVEIRA, 2004).

O ideário da racialização atua como um mecanismo construtor de imagens distorcidas da historicidade e da cultura negras, ligando diferentes elementos simbólicos para justificar e validar a hierarquização entre os seres humanos. Os corpos negros, os cabelos enrolados, as artes africanas, as culturas negras são tomados como expressões máximas para a construção da inferioridade dos sujeitos negros, servindo como elemento para a alocação dos homens, mulheres e crianças pequenininhas de pele escura nos lócus mais baixos da hierarquia social (GOMES, 2008).

Nesse processo, como ressalta Fernandes (1972), os brancos desfrutam de grandes privilégios, como se a ordem social vigente estivesse posta para garantir somente aos interesses préestabelecidos por e para este grupo, fundando abismos sociais pautados em diferenças fenotípicas que cunham processos de exclusão, existindo a criação de laços ideológicos que constroem e advogam a existência não só de uma distância social e cultural entre negros e não negros, mas também biológicas.

Para a construção efetiva de uma hegemonia branca, são criados mecanismos de anulação das culturas não dominantes, o que, no contexto brasileiro, significa criar abismos entre os negros e os não negros. Esses mecanismos atuam, segundo argumenta o sociólogo Ianni (1988), como uma técnica social de manipulação do comportamento de pessoas ou grupos, dividindo-os ou aglutinandoos, da mesma forma que as organizações religiosas. Essa percepção se impregna nas diferentes ações estabelecidas cotidianamente, impedindo que possa existir uma troca simbólica destituída de qualquer padrão "hierarquizador" entre brancos e não brancos. 
Os negros dentro desse processo são "forçados a rejeitar os seus corpos", construindo um referencial sobre o que é belo a partir de um referencial eurocêntrico de beleza - o colonialismo que os toma e limita o seu existir enquanto o outro, desnudando sua humanidade e fundindo a ideia de inferioridade corporal e cultural, marcando sua subjetividade com um racismo constante (FANON, 2008; GOMES, 2008).

Ao mesmo tempo que o processo de racialização produz a inferioridade do negro através do olhar do outro, também legitima a aculturação forçada pelo imperialismo colonial, criando imagens tomadas como modelos ou referências. Nesse sentido, não basta somente alocar os negros em condições subalternas, é necessário também negar sua negritude $^{3}$ e criar um imaginário negativo sobre ela, desenvolvendo a concepção de que as produções culturais dos europeus brancos são as melhores para compor as instrumentalidades da vida: a chamada "civilização" - a cultura "hegemônica" da classe dominante.

A violência gerada por esse processo cria sentimentos como o medo, a rejeição e a baixa autoestima dos sujeitos negros, segundo Miskolci (2005, p. 685), "gera subjetividades autodestrutivas em busca de adequação a qualquer custo". Como exemplo dessa violência, podemos mencionar um fato ocorrido no mês de outubro durante a realização das atividades em comemoração ao dia das bruxas.

Durante a realização das atividades do dia das bruxas, na hora do sono, Zacimba ${ }^{4}$ menina negra de 3 anos) acorda chorando e a docente vai ao encontro dela e pergunta:

- O aconteceu?

- Eu tenho cabelo de bruxa, igual àquela história ${ }^{5}$ que você contou...

- Por que você tem cabelo de bruxa? Bruxa não existe!

- O meu cabelo é assim (pausa) [a menina aponta para os seus cachos], igualzinho o da bruxa, todo armado!

- Mas você não é bruxa...

- Olha lá o cabelo dela, é igual ao meu!

- O seu não é de bruxa, ele não fica armado sempre, existe muitas coisas que deixam ele baixinho.

A docente abraça a menina e a leva tomar água no refeitório.

(Fragmento do Caderno de Campo, 23 de outubro de 2012).

A menina negra, ao se levantar chorando por acreditar que seus cabelos a tornam uma bruxa - personagem dentro do ideário infantil brasileiro responsável por fazer mal às crianças pequenininhas - revela o peso de um padrão estético que liga o conceito de belo aos 
cabelos lisos, às tonalidades de pele clara, apresentando a influência negativa que estes padrões exercem sobre os sujeitos. Diante de um espaço racializado, como o do Centro de Educação Infantil pesquisado, uma história com bruxa de cabelo armado tem uma conotação diferenciada, uma vez que fornece imagens negativas do que é ser alguém com aquele tipo de cabelo, fundando a ideia de que é ruim ter cabelos esteticamente semelhantes aos da personagem.

A docente 6 , ao dizer: "O seu não é de bruxa, ele não fica armado sempre, existe muitas coisas que deixam ele baixinho", também pode expressar uma rejeição aos cabelos crespos da menina, apresentando um incômodo quanto a sua forma. No entanto, não podemos esquecer que a docente é parte de uma sociedade racista e, ao fazer tal afirmação, ressalta o ideário presente na mesma. Esse episódio, dentro das circunstâncias descritas, expressa a violência colonial sobre a estética negra presente nas diferentes instâncias da sociedade, não correspondendo a uma característica pessoal da docente.

A institucionalização estética racial do cabelo liso como belo e prático parece ressoar sobre todos os sujeitos presentes na sociedade, marcando não somente as subjetividades dos sujeitos negros, mas também dos brancos com cabelos crespos ou enrolados. Contudo, é importante salientar que os cabelos crespos somados à pele negra na sociedade brasileira funcionam como signos de comunicação das relações raciais que vivenciamos cotidianamente, expressando as rupturas históricas realizadas frente ao pacto colonial.

Começo a sofrer por não ser branco, na medida em que o homem branco me impõe uma discriminação, faz de mim um colonizado extorque de mim todo o valor, toda originalidade, diz que parasito o mundo, que acompanhe o mais rápido possível o mundo do homem branco. Eu tentarei simplesmente tornarme branco, isto é, desobrigarei o Branco a reconhecer a minha humanidade (FANON, 2008, p. 82).

A racialização presente na adjetivação dos cabelos negros como "ruins", cria elementos para o descolamento de um pertencimento corpóreo dos sujeitos negros, desencadeando um processo de negação de si mesmo e de seu grupo racial. Nesse sentido, para Gomes (2008), assim como a democracia racial encobre os conflitos raciais, a institucionalização de um padrão liso para os cabelos camufla a possibilidade de um pertencimento étnicoracial africano, não permitindo a construção de uma ligação direta com as ancestralidades negras e também o reconhecimento de beleza étnico-racial distinta da europeia. 
A hierarquização dos sujeitos com base em princípios coloniais de racialização agrava e justifica as desigualdades entre os humanos. Nesse processo, como aponta Fernandes e Bastide (2008), a cor negra foi selecionada como marca racial que serviria para identificar socialmente aqueles que deveriam ficar em níveis mais baixos da sociedade. A quantidade de melanina na epiderme humana "passou a ser um símbolo de posição social, um ponto de referência imediatamente visível e inelutável, através do qual se poderia presumir a situação de um indivíduo isolado, como socius e como pessoa, tanto quanto definir o destino de uma raça" (FERNANDES; BASTIDE, 2008, p. 95).

Essas ideias de racialização influenciam as culturas infantis, criando singularidades e cunhando imagens de uma infância e do que é ser criança em uma sociedade desigual e hierarquizada racialmente. Contudo, esse processo não é natural nem indolor; muitas vidas são relegadas ao esquecimento para que a norma substantiva dos signos, impregnada sobre os corpos, seja legitimada. As crianças pequenininhas passam a constituírem-se como sujeitos do meio social, absorvendo papéis e atitudes dos significados presentes na sociedade, interiorizando-os, tornando-os seus.

Como de costume a docente pede para as crianças formarem uma fila na hora do lanche. No entanto, hoje ocorre uma confusão entre as crianças e Dandara (menina negra) começa a chorar. A docente olha brava para as crianças e pergunta:

- O que está acontecendo? Por que Dandara está chorando?

Duda responde:

- Porque eu empurrei ela! Ela é suja toda preta! Iria me deixar suja!

A docente olha a cena e diz:

- Dandara não perturba a Duda, vai para outro lugar e lava esse rosto, já estou cansada de brigas entre vocês. E Duda deixa de ser nojenta, para de implicar com a Dandara, cada uma tem um jeito! Para de encher o saco uma da outra!

(Fragmento do Caderno de Campo, 28 de agosto de 2012).

Ao considerar a sua colega negra como suja, Duda impõe uma identidade racializada para a menina pequenininha, criando a ideia e a percepção de que ser negro é ser sujo, e que, por este motivo, ela não teria o direito de convivência com outras crianças, interditando até mesmo a possibilidade de lhe dar a mão. Ao longo dessa dinâmica, surgem situações em que muitos constrangimentos causados pelo racismo se tornam visíveis, impregnando na subjetividade dos sujeitos negros, deixando marcas que os acompanharão ao longo da vida.

Esse acontecimento pode parecer apenas um detalhe no cotidiano da educação infantil, mas influencia diretamente a 
construção de uma percepção racializada dos sujeitos, podendo gerar sentimentos de recusa às características raciais do grupo negro e fortalecer o desejo de pertencer ao grupo branco. É importante também salientar que a postura da docente em silenciar-se frente ao preconceito racial exposto, sinaliza à criança discriminada que ela não pode contar com a cooperação de seus/suas docentes. Por outro lado, para a criança que discrimina, sinaliza que ela pode repetir a sua ação visto que nada é feito, seu comportamento nem sequer é criticado no âmbito do preconceito racial.

Contudo, a criança pequenininha negra não apresenta apenas um comportamento passivo diante das manifestações racistas. Como podemos observar, Dandara chora, demostrando o seu incomodo em relação ao preconceito que ela vivencia quando a sua colega de sala a discrimina. Por meio da análise dos dados, é possível observar que em diferentes momentos as meninas e meninos pequenininhos/ as negras/os expressam através de inúmeras linguagens os seus os incômodos - resistências frente aos processos racistas.

\begin{abstract}
Estava sentado ao lado da docente (branca) observando um ritual diário: o pentear os cabelos das crianças. Conforme as crianças iam despertando do sono da tarde, eram chamadas nominalmente para pentear os seus cabelos. Algumas fingiam que não escutavam e tentavam dormir novamente, outras já corriam para o encontro da docente e diziam que queriam ficar como princesas ou príncipes. Como um movimento mecânico, a maioria das crianças levantavam, esfregava os olhos e iam ao encontro da docente para que ela penteasse seus cabelos.

No entanto, Dandara (uma menina negra) não procedeu dessa forma, diferentemente das outras crianças acordou e foi brincar isolada no canto da sala. Curiosamente a docente não a chamou para pentear os cabelos naquele momento. Após a docente pentear todos os cabelos das outras crianças ela diz:

- Dandara, vem pentear seu cabelo! Ela sempre faz isso, fica correndo pela sala (pausa), não gosta de pentear o cabelo, mas é por que o cabelo dela é assim....! (Pausa prolongada) Ela faz cara feia, pois tenho que puxar para ficar assentado!

Dandara olha para a docente com olhos murchos e sai correndo em direção ao corredor do Centro de Educação Infantil. Chora, grita e resmunga ineficientemente, pois a docente a pega no colo e penteia seus cabelos prendendo todos seus cachos. A menina me olha, esfrega as mãos nos olhos, e respira profundamente, mantendo sempre no semblante facial traços de raiva.
\end{abstract}

(Fragmento do Caderno de Campo, 25 de setembro de 2012).

Dandara, ao recusar-se a pentear os cabelos, apresenta uma posição a favor da vida, procurando desvincular de si o adorno de cabelo ruim, fugindo do arcabouço simbólico que a liga a um estereótipo construído com base em uma ideologia racial segregacionista e expropriadora da humanidade dos sujeitos negros. O movimento 
criado pela menina procura romper com os enquadramentos sociais racistas, mas também não é a mera imposição de sua vontade, nem a realização simples de um desejo ou um prazer, antes de tudo é a exposição da necessidade de mudanças.

A menina pequenininha negra produz, de modo não adultocêntrico, uma resistência contra os enquadramentos, deixando explícita a sua rejeição frente à imposição normativa que procurava aprisionar seus desejos. Estar com os cabelos crespos livres do racismo seria um ato de reinvenção de si e criação de outros modos de vida. Deste movimento emerge uma série de lutas heterogêneas, por exemplo, contra uma estética fascista, contra o racismo, pela liberdade do corpo da menina em permanecer livre de adornos sociais que a caracterizam como pertencente a uma posição social subalterna, que colocam em xeque as micropolíticas de dominação normativa e seus prolongamentos. O movimento provocado por ela cria uma estética antipadronizadora, anticlassificatória, desestabilizando os pilares coloniais impostos pelos enquadramentos sociais, de modo que a ideologia racista, por alguns instantes, é impedida de colar, impregnarse ou atuar sobre sua pele e "contaminar" sua subjetividade.

Os movimentos de resistências construídos por Dandara foram observados em diferentes momentos, por meio de gritos sem palavras: ochoro, o "silenciamento", o não quererse relacionar, etc. A meninaresistia, expressando através de diferentes linguagens, seu descontentamento frente aos atos racistas que atravessavam a sua subjetividade. Podemos perceber que, em alguma medida, estes movimentos, tanto no momento em que a Duda considera Dandara como suja, por ser negra, quanto no momento em que a menina quer ficar sozinha e não pentear os cabelos, expressam seu aborrecimento, seu desgaste frente a situação que a cerceia. De algum modo ela está procurando dizer, mesmo que sem palavras, o que sente, o que não deseja.

Dandara também foge da dor que sente em pentear seus cabelos - a racialização, ao mesmo tempo que atravessa a subjetividade, a faz sentir "dores físicas disciplinantes", colonizando seu corpo com padrões e regras que legitimam a hierarquização social presente no ideário racial. Rosa (2009), em sua dissertação de mestrado, mostrou como muitas vezes as instituições de educação infantil produzem racialmente as diferenças das crianças pequenininhas. Como exemplo, a pesquisadora expôs que muitas creches não possuem escovas adequadas para pentear os cabelos dos meninos e das meninas pequenininhos/as negros/as, limitando às crianças negras aos cuidados inadequados, construindo a ideia de que seus cabelos 
são ruins e por isso não é possível penteá-los com qualquer escova. Esse processo não é simples carência de materiais adequados, mas também humilhação: um atentado contra o ser.

Dandara e as outras crianças negras gritavam cotidianamente suas insatisfações frente aos processos de discriminação racistas, contudo, a colonização adultocêntrica tenta impedir que percebamos as resistências à racialização. Muitas vezes acreditamos que um choro possa somente expressar a vontade de dormir de um menino pequenininho ou uma menina pequenininha, ou mesmo uma pequena rebeldia desnecessária, ao invés de representar uma insatisfação frente a uma ação racista que a toca. $\mathrm{O}$ adultocentrismo não permite olhar e ouvir o que as crianças pequenininhas querem nos transmitir, nos deixando amarrados em padrões de linguagens e de comportamentos que muitas vezes não correspondem à "intempestividade" da própria infância. Dentro desse contexto, as culturas infantis são fetichizadas como meros elementos reprodutores do mundo adulto, e a infância se torna assim um espaço de simples cópia, destituído da possibilidade de produção de cultura e ressignificação do mundo.

No espaço em que realizei a minha pesquisa de campo, em diferentes momentos pude observar que outras crianças pequenininhas negras criavam estratégias para fugir do processo de racialização que as atravessava. Entre os inúmeros momentos de resistência, gostaria de destacar outro episódio:

De modo muito semelhante aos dias anteriores a docente (branca) da sala repreendia de modo frenético Folayan (menino negro de 3 anos). Contudo, em minha percepção, o menino estava agindo de modo semelhante a outras crianças:

- Folayan, eu já não falei para você que não pode ficar correndo pela sala! Aqui é uma escola, e não a sala da sua casa!

- Folayan, para de causar confusão! Assim você é chato!

- Folayan, fica quieto! Nossa, esse menino está um furacão hoje! Parece até um macaquinho de tanto que pula!

- Folayan, eu disse para você brincar aqui no canto e não ficar enchendo o saco da Tabata (menina branca)! Deixa a nossa princesa brincar quietinha!

Após a última vez que foi chamado a atenção, Folayan olha, olha para a Tabata (a princesa da sala) e a morde, a docente desesperada corre ao encontro da menina e começa a gritar:

- Folayan, vem já aqui, você vai para a diretoria! Onde já se viu morder os outros assim! Você não tem jeito, fica pulando, gritando, não me dá paz! Parece um demônio!

A docente pega o menino pelo braço e o leva para a diretoria. Como nesta semana ele já tinha ido três vezes para a direção por falta de obediência, a diretora pediu para que ele fosse colocado por um tempo em outra sala. 
O curioso neste momento é que na outra sala, o menino parecia se comportar, pois quando a docente foi buscá-lo para tomar o lanche da tarde, a outra docente (branca) disse que ele não bateu, não brigou, e ficou comportado.

O menino havia agido de modo muito semelhante nos dias anteriores, então quando ele retornou à sala resolvi perguntar para ele porque ele batia em um amigo sempre quando a docente chamava a atenção, e ele de um modo brilhante me respondeu somente sorrindo e saiu para brincar.

(Fragmento do Caderno de Campo, 28 de novembro de 2012)

Folayan, ao ser expulso da sala, consegue se livrardo autoritarismo presente na prática pedagógica exercida pela docente, "deixando trancadas nas paredes das salas" que ele é obrigado a frequentar, todas as relações repressivas, castradoras e racistas que o atravessavam. $\mathrm{O}$ ato de permanecer fora daquele lugar é uma possibilidade para o menino pequenininho negro criar uma nova vida, descolada da identidade de menino bagunceiro, podendo estar livre por alguns segundos de todas as algemas racistas que o prendiam. Vilela (2006) afirma que resistir é criar, é pensar o mundo como possibilidade de se estabelecerem novos modelos de existência. No caso de Folayan, ao sair da sala, ele cria a possibilidade de viver uma vida, por algum tempo, longe das cobranças racistas impelidas pela professora.

O ato de resistir, para Deleuze e Guattari (1995), é fundado na criação da vida, nos entremeios dos blocos de invenções, sensação e afetos, constituindo-se enquanto força que lança os homens, mulheres e crianças para além-do-homem, além-da-mulher e além-da-criança, engendrando heterotopias.

É importante ressaltar que Folayan poderia ter ficado isolado na outra sala, ou com medo, contudo, isso não importa; o que procuro ressaltar neste momento não é se ele brincou ou não na sala para a qual ele tinha sido alocado, o que procuro explicitar é a força de ruptura que esse menino impele para repelir os elementos normativos que o sufocam sob a conduta de um enquadramento racista.

Esse movimento construído pelo menino pequenininho negro explicita a não aceitação do racismo que atravessa sua subjetividade, criando a possibilidade de outras condutas, isto é, uma "contraconduta", segundo Foucault (2008), que se afirma enquanto um movimento que busca a legitimação de outros modos de condução, ou seja, tem como finalidade "escapar da conduta castradora dos outros", procurando "definir para cada um a maneira singular de se conduzir" (FOUCAULT, 2008, p. 24). Trata-se de produzir a diferença, desterritorizar a norma e incitar a criação de novas vidas (GALLO, 2007). 
O menino pequenininho negro também poderia somente querer demonstrar sua insatisfação quanto à repressão que sofreu, pois essa situação ocorria diariamente com Folayan, diferentemente de outros meninos pequenininhos brancos que também faziam "bagunça" e não eram repreendidos.

Os gritos e os xingos da docente estabeleciam uma experiência castradora para Folayan, "uma experiência de aprisionamento, de morte", não deixando espaço para a construção de outras formas de existir a não ser daquela que ela estipulava. A morte, dentro desse contexto, abandona sua percepção somente biológica e passa a se caracterizar também como a falta de perspectiva de existência, homogeneizando os padrões da vida. Como argumenta o filósofo Agamben (2006), tal processo não tem nenhum conteúdo factual positivo, pelo contrário, "ele é a possibilidade da impossibilidade da existência em geral, do esvanecimento de todo existir" (AGAMBEN, 2006, p. 18).

A perversidade desse processo é o apagamento das diferenças e a instituição do "reino do mesmo". Nesse contexto, é construído um padrão a ser seguido, que tenta "matar" todas as formas distintas de expressão, subjetividades e linguagem, de modo que o outro é sacrificado em prol da manutenção desse padrão.

Do ponto de vista do racismo, não existe exterior, não existem as pessoas de fora. Só existem pessoas que deveriam ser como nós, e cujo crime é não o serem. A cisão não passa mais entre um dentro e um fora, mas no interior das cadeias significantes simultâneas e das escolhas subjetivas sucessivas. $\mathrm{O}$ racismo jamais detecta as partículas do outro, ele propaga as ondas do mesmo até à extinção daquilo que não se deixa identificar (ou que só se deixa identificar a partir de tal ou qual desvio). Sua crueldade só se iguala a sua incompetência ou a sua ingenuidade. (DELEUZE; GUATTARI, 1995, p. 45-46).

O racismo tenta construir a ideia imperativa de "morte" das diferenças étnico-raciais, contudo, as crianças pequenininhas negras gritam "vida". O mesmo poder que achata as singularidades recebe violentamente uma força de resistência que o impede de apagar e construir um espaço homogêneo e linear. Os choros, as rebeldias infantis são armas de uma guerrilha a favor da vida; transmutações concretas de resistência pela não pasteurização dos sujeitos.

Podemos aqui tomar conceitualmente a hipótese mais instigante da analítica foucaultiana para entender os processos de resistência infantis: "não existem relações de poder sem resistências, estas são na mesma proporção mais reais e mais eficazes, pois se formam lá mesmo onde se exercem as relações de poder" (FOUCAULT, 1990, p. 91-92). 
O variável grau de força das ações de resistência atinge grupos, indivíduos e, principalmente, a vida, alteram modos de agir e provocam fragmentos na sociedade, se rearticulam não na síntese dialética, mas num afrontamento inexorável. Quer dizer, da mesma forma que as redes das relações de poder acabam formando um tecido espesso que atravessa os aparelhos e instituições, sem se localizar exatamente neles, também a pulverização dos pontos de resistência atravessa as estratificações sociais e as unidades individuais. E é certamente a codificação estratégica desses pontos de resistência que torna possível uma revolução, um pouco à maneira do Estado que repousa sobre a integração institucional das relações de poder (FOUCAULT, 1990, p. 92).

A partir dos pressupostos de Foucault (1990) podemos compreender a extremidade do poder e a resistência como forças do mesmo campo, não existindo um poder destituído de qualquer resistência. Nesse sentido, ao mesmo tempo que se produz uma racialização, se cria uma força de repulsão desse processo, seja através de modelos naturalizados pela sociedade enquanto movimentos de resistência, seja por ações intersubjetivas de negação da ordem prescrita e da normatividade apresentada.

Com base nesse pressuposto, podemos questionar a suposta passividade construída sobre linguagens infantis como choros, gritos e desânimos das crianças. Essas podem ser expressões de um movimento de resistência frente ao poder exercido pelo universo adulto sobre os corpos infantis. Os choros, bem como outras manifestações de desobediência das crianças negras, podem ser entendidos como discurso de discordância dos enquadramentos sociais racistas impostos pelas práticas pedagógicas presentes na educação infantil. Por meio de diferentes movimentos de choque com o poder, os meninos e meninas negros instauravam sentidos e "rabiscavam" suas configurações corpóreas, lançando-se para o novo, resistindo, de modo a criar uma nova possibilidade de existência, fora de si, além-do-homem. Como nos ensina Zaratustra (NIETZSCHE, 2003):

O homem é algo que deve ser superado. Que fizeste para superá-lo? Todos os seres, até agora, criaram algo para além de si mesmos. Quereis antes ser a vazante dessa grande maré cheia e retroceder ao animal, em vez de superar o homem? Que é o macaco para o homem? Um riso ou uma dolorosa vergonha. E mesmo isso deve ser o homem para o além-do-homem: um riso ou uma dolorosa vergonha. (...) Vede, eu vos ensino o além do homem. O além do homem é o sentido da terra. Vossa vontade diria: "o além do homem seria o sentido da terra" (NIETZSCHE, 2003, p. 3).

A compreensão nietzschiana do além-do-homem como "sentido da terra" incita-nos a pensar o que é, e quem é, o padrão dentro do referencial de normalidade prescrita nos espaços do 
Centro de Educação Infantil. Do mesmo modo que Zaratustra (NIETZSCHE, 2003) provoca-nos a ir para além do homem, as crianças provocam- nos a ir além do conceito de raça, reinventando os lóci que o processo de racialização delimita para a sua existência.

As resistências são reações produtivas ao processo de radicalização castrador da vida, de modo a afirmar sentimentos, vontades, necessidades, construindo a possibilidade de vida no momento em que ela deixa de existir. Noal (2013) aponta essa multiplicidade de movimentos de resistência, explicitando o riso como uma das formas que ela pode assumir. Para a autora, a linguagem do riso facial, para o povo Guarani-Kaiowá, não é apenas um movimento de músculos, podendo significar também uma aceitação, uma aquiescência; mas pode também ser a expressão de uma recusa interna, de uma transgressão que não quer se expor para não enfraquecer. $\mathrm{O}$ riso, nessa perspectiva, não deve ser banalizado, mas estudado e compreendido como uma das possíveis estratégias de sobrevivência das sociedades sobre as quais as projeções estatísticas já asseguravam que não existiriam nestes nossos tempos.

As resistências existem no plural, distribuídas no tempo e no espaço de modo irregular. De forma pulverizada atravessam as estratificações sociais e as unidades individuais, podendo provocar a mobilização de grupos ou indivíduos.

[...] o que seja a resistência o sabemos com certa precisão, uma vez que na vida cotidiana uma grande maioria de sujeitos sociais se encontra exercendoa. Nas atividades produtivas, contra um padrão; nas atividades da reprodução social, contra as autoridades que regulam e contra a vida (na família, o paternalismo...); na comunicação social, contra os valores e os sistemas que fecham a experiência e a linguagem na repetição e os empurram para a ausência de sentido. A resistência interage duramente, mas também criativamente, com o comando, em quase todos os níveis da vida social vivenciada (NEGRI, 2003, p.197).

Como apresenta Foucault (1999), os pontos de resistência são, na maioria das vezes, transitórios e introduzem na sociedade "clivagens que se deslocam, rompem unidades e suscitam reagrupamentos, percorrem os próprios indivíduos, recortando-os e os remodelando, traçando neles, em seus corpos e almas, regiões irredutíveis" (FOUCAULT, 1999, p. 92). As crianças pequenininhas, ao chorarem, gritarem, baterem e morderem, em certa medida, estão dizendo que desejam outros modos de vida, outras possibilidades de "experienciar" a vida dentro do Centro de Educação Infantil.

Os pontos, os nós, os focos de resistência disseminam-se com mais ou menos densidade no tempo e no espaço, às vezes provocando o levante de grupos ou 
indivíduos, de maneira definitiva, inflamando certos pontos do corpo, certos momentos da vida, certos tipos de comportamento. Grandes rupturas radicais, divisões binárias e maciças? (FOUCAULT, 1999, p. 92).

Certamente, para Foucault (1999), as resistências não são necessariamente grandes mecanismos de ruptura de um sistema; elas podem ser entendidas como ações orgânicas de criação de vida para além de um modelo pré-determinado, sejam as resistências criadas no embate frontal entre estruturas de poder, ou ressignificações micropolíticas de técnicas políticas de sustentação da vida.

Esses processos não se constituem antagonicamente à racialização; não passam apenas por definir quem são os contrários, mas tomam como centro a desconstrução de uma falsa unidade racial. O poder colonial de racialização não é algo onipotente e onisciente que captura todos os sujeitos. Como ressalta Foucault (2001), "desde que há uma relação de poder, há uma possibilidade de resistência. Nunca somos pegos na armadilha pelo poder, sempre podemos modificar o domínio, em determinadas condições e segundo uma estratégia precisa" (FOUCAULT, 2001, p. 267).

Uma das formas mais comuns de resistência ao racismo das crianças, como afirma Dias (2012), é a reação de agressão que algumas crianças negras exercem sobre as outras. Nem sempre as instituições educativas têm a percepção de que esses atos são representações de um processo violento sofrido anteriormente, distinguindo as crianças que exercem esse ato através de exclusões que as categorizam como "agressivas", "esquisitas" ou "pouco participativas".

É necessário que as pedagogias e as pesquisas em educação deem oportunidade para as crianças serem ouvidas, pois como destaca Faria (2007), voz elas têm, e como já dito, aproveitam-se dela. Portanto, precisamos ouvi-las mesmo quando elas ainda não falam, não andam, não leem e não escrevem, tornando possível reconhecêlas como capazes de estabelecer múltiplas e potentes relações, com um alto e sofisticado grau de comunicação com crianças de mesma ou de idades diferentes e com os adultos. Contudo, temos de ter claro que a escuta das crianças pequenininhas ultrapassa a mera decodificação de palavras verbais, existindo a necessidade de se ouvirem outros sons, outras formas de comunicação, de perceber também as linguagens corpóreas das meninas pequenininhas e dos meninos pequenininhos.

As linguagens infantis são elementos simbólicos que possibilitam produção de uma cultura dentro do grupo com outras crianças e nas relações com os adultos. Esse movimento conduz-nos a pensarmos que as crianças também são sujeitos que fazem história 
e que constroem cultura em condições dadas pela sociedade que pertencem (FERNANDES, 2004).

No entanto, as pedagogias de educação infantil, presentes em muitas creches e pré-escolas, ainda são impregnadas por um colonialismo adultocêntrico que tenta impedir de ver as culturas infantis como elementos singulares no fazer cotidiano das instituições. Dentro desse contexto, as múltiplas linguagens infantis são inviabilizadas como elementos construtores das culturas infantis: o choro vira rebeldia, as mordidas se tornam agressividade, e o silêncio, patologia psíquica.

Os meninos e as meninas pequenininhos/as são renegados/as somente ao status de passivos/as, produzindo uma imagem da infância vazia, sem produções simbólicas e sem criações culturais. Felizmente, essa hipótese não é verificável, pois as crianças produzem cultura nas relações com seus pares, não simbolicamente adultocêntrica, mas intempestiva, inconstante e transgressora.

\section{GRITOS, MORDIDAS, SORRISOS: LINGUAGENS INFANTIS E A PRODUC̣ÃO DA CULTURA}

Os sons que ecoam pelos corredores da educação infantil nos dizem muito mais do que barulhos, nos mostram a força que as crianças pequenininhas projetam a fim de resistirem à violência dos enquadramentos sociais racistas. As crianças pequenininhas resistem em favor da vida, procurando deslegitimar a lógica racista presente em muitas ações realizadas pelos/as docentes. Por meio de seus atos, elas procuram mostrar que querem ser reconhecidas de outras formas, que muitas vezes não correspondem às pré-estabelecidas pelos enquadramentos sociais.

No entanto, nem sempre essas linguagens infantis são ouvidas; muitas vezes são deixadas à margem, esquecidas na insensibilidade construída pelo colonialismo. Dentro desse processo, os meninos e meninas pequeninhos/as gritam, os/as docentes resmungam e ninguém se ouve, a impossibilidade de escuta assola o adultocentrismo e legitima todas as formas de racismo.

Aqui reside uma das chaves fundamentais para a construção de uma educação antirracista, pois somente através da ruptura do "pacto colonial adultocêntrico" e da ampliação do olhar para as culturas infantis é que será possível criar elementos que possibilitem destruir as amarras racistas presentes no cotidiano das creches e pré-escolas.

As crianças pequenininhas dizem muito sobre as relações raciais, fornecendo, através dos seus discursos, subsídios para a 
construção de pedagogias descolonizadoras, as quais podem ser fundamentadas no movimento intempestivo da própria infância. Os choros, as mordidas, as risadas, as palavras infantis nos fornecem elementos para pensarmos as ações docentes, proporcionando questionamento constante dos nossos posicionamentos políticos frente ao processo de segregação racista.

Como afirma o poeta Mário de Andrade (2006), ouvir é um ato que não deve conter qualquer tipo de preconceito. Tem de ser desinteressado. Para o poeta, o verdadeiro ouvinte "é aquele que, livre de todos os preconceitos, ignorando todos os ídolos, se conserva naquela exata atitude de contemplação passiva que lhe permitirá gozar e amar" (ANDRADE, 2006, p.67).

Por meio de inúmeras linguagens, os meninos pequenininhos e as meninas pequenininhas produzem uma cultura infantil que demonstra sua insatisfação frente à discriminação e ao rechaçamento a que são expostos/as, não sendo passivos/as a esse processo; por meio de diferentes linguagens demonstram essa violência que marca seus corpos, criando movimentos que possibilitam serem vistas, mesmo que para isto seja necessário promover ações que à primeira vista possam parecer estranhas ou inadequadas.

A superação do racismo está diretamente ligada à possibilidade de escuta do outro, não sendo possível eliminar esse imperativo colonial sem nos abrirmos a conhecer os diferentes sujeitos que compõem nossa sociedade. A potencialidade da desconstrução da lógica racista através da escuta das linguagens infantis desestabiliza o imperialismo adultocêntrico, possibilitando a criação de novas relações entre adultos e crianças na educação infantil.

As meninas pequenininhas negras e os meninos pequenininhos negros demostram sua insatisfação através das suas diferentes linguagens: gestos, movimentos, emoções, choros, silêncios, olhares, barulhos... Mesmo quando muito pequenininhos, estabelecem trocas simbólicas com coetâneos e adultos, através de uma rede complexa de linguagem (FARIA, 1999).

O processo de colonização adultocêntrica, que retira das crianças suas linguagens e as condicionam a assumir somente a oralidade como um meio de comunicação com o mundo, também constrói padrões do que sejam a imaginação, o desejo e o modo que meninos e meninas pequenininhos/as devem se relacionar com o mundo. Através desse processo, as diferenças singulares produzidas pelas múltiplas linguagens infantis são anuladas, criando um imaginário de uma língua única e homogênea para a comunicação. 
As crianças pequenininhas, dentro desse contexto, são excluídas e hierarquizadas em diferentes dimensões, existindo um processo de homogeneização linguística que, ao mesmo tempo que padroniza, também segrega. Desse modo, retomamos as resistências infantis enquanto uma das cem linguagens das crianças, comunicando de diferentes formas o posicionamento das crianças pequenininhas diante do mundo. As resistências produzidas pelas crianças pequenininhas negras são de cunho "poético". Transcendendo a utilidade monolinguíssima da fala, os gestos, os choros, os gritos se tornam metaforicamente armas de guerra contra os enquadramentos coloniais de segregação racial. As poéticas produzidas por essas cem linguagens penetram nas entranhas das relações de poder que sufocam, matam e mutilam cotidianamente as subjetividades infantis.

O ato de resistência possui duas faces. Ele é humano e é também um ato artístico. Somente o ato de resistência resiste à morte, seja sob a forma de uma obra de arte, seja sob a forma de uma luta dos homens (DELEUZE, 1995, p. 129).

Com base nos pressupostos de Deleuze e Guattari (1995), não tomo a resistência como algo duro, mas, sim, artístico e criador, movendo os sujeitos para além deles próprios, destruindo a tênue fronteira entre a imposição do poder sobre a vida e a criação da vida pelas próprias crianças. Neste sentido, resistir é não se calar quando todos desejam o silêncio; é brincar durante o castigo atrás da porta; é poder ter a sensação de estar livre por algum tempo; é poder... é poder criar...

Interessante nesse movimento é a possibilidade de produção das linguagens infantis que expressem resistência, rebeldia frente ao enquadramento, criando sua própria língua como um estrangeiro. Desse processo deriva um elemento extraordinário que ao mesmo tempo dispara e coroa a resistência política que se faz na própria linguagem: trata-se da emergência de um estilo, para além de quaisquer capturas normativas (DELEUZE; GUATTARI, 1995).

Os gritos de insatisfação, os movimentos artísticos de resistências criados pelas crianças pequenininhas corrompem a lógica do silêncio, criando palavras de ordem escritas sem nenhum grafismo, recriando a vida e modificando as lógicas artísticas que existem dentro de uma creche e pré-escola.

Intranquila e desconfiada da própria mudez, a palavra enroscou-se em fios emaranhados que a forçavam a lançar-se fora do não-dito. O campo de forças criado pelos fios apontava à palavra a fala. Mas a palavra queria tanto o silêncio. E só alcançava a impossibilidade do preferir não falar e ter que ficar muda.

A palavra pensava, não por palavras, mas com imagens, opacas, sobrepostas, áridas, desfocadas e insanas. As imagens enlouqueciam a palavra, deixavam-na 
enfurecida, deslocada de um alfabeto que a ordenasse. Será que, para encontrar o silêncio, só mesmo com a morte da palavra? [...]

A palavra estava sem-lugar. Desassossegada, a palavra coçou-se inteira e em partes, e foi expelida ao vento, em sementes voadoras, em bicos de pássaros, em línguas dissonantes, em correntezas de ar e de água, nos brilhos das gotas de orvalho que são feridos pelos raios do sol, na poeira depositada em chão. [...]

Escuta? (AMORIM, 2012, p. 2-4).

Ao encontro desse pensamento, propomos como um dos princípios básicos para a construção de uma educação das relações étnico-raciais a desinibição dos ouvidos para a escuta de diferentes linguagens infantis. Faz-se necessário escutar os ruídos das paredes, dos móveis, os dizeres proferidos pelas crianças pequenininhas - é indispensável que os/as docentes se ouçam. A educação das relações étnico-raciais somente será legitimada quando todos os elementos que constroem a educação infantil se escutarem, conversarem, discordarem, e produzirem a diferença como elemento produtivo da pedagogia da infância desenvolvida pela instituição. É necessário ouvir. Escuta?

\section{REFERÊNCIAS}

ABRAMOWICZ, A; LEVCOVITZ, D. Tal infância: qual criança? In: ABRAMOWICZ, A.; SILVERIO, V. R. Afirmando diferenças: montando o quebra-cabeça da diversidade na escola. Campinas: Papirus, 2005. p. 73-86.

ABRAMOWICZ, A. A pesquisa com crianças em infâncias e a sociologia da infância. In: FARIA, A. L. G.; FINCO, D. (Orgs.). Sociologia da Infância no Brasil. Campinas: Autores Associados, 2011. p. 1-17.

AGAMBEN, G. A Linguagem e a Morte. Belo Horizonte: Ed. UFMG, 2006.

AMORIM, A, C. R. O mundo grita: escuta? Linha Mestra, Campinas, ALB, v. 1, p. 1-4, 2012.

ANDRADE, M. Música, doce música. São Paulo: Martins, 2006.

BARBOSA, M. C. S. Culturas escolares, culturas de infância e culturas familiares: as socializações e a escolarização no entretecer destas culturas. Revista Educaşão e Sociedade, Campinas, v. 28, p. 1059-1083, 2007.

BASTIDE, R; FERNANDES, F. Negros e brancos em São Paulo. São Paulo: Companhia Editora Nacional, 1959.

BHABHA, H. O local da cultura. Belo Horizonte: Editora UFMG, 2007.

CAVALLEIRO, E. S. Do silêncio do lar ao silêncio escolar: racismo, preconceito e discriminação na educação infantil. São Paulo: Contexto, 2003.

CASHMORE, Ellis. Dicionário de relacõoes étnicas e raciais. Tradução: Dinah Kleve. São Paulo: Summus, 2000.

CORSARO, W. Sociologia da infância. 2a . ed. Porto Alegre: Artmed, 2011.

CUNHA JUNIOR, H. et al. A criança (negra) e a educação. Caderno de Pesquisa, São Paulo: Fundação Carlos Chagas, v. 1, n. 31, p. 69-72, dez 1979. 
DELEUZE, G.; GUATTARI, F. Introdução: Rizoma. In: Milplatôs. Rio de Janeiro: Ed. 34, 1995. v. 1. p. 10-37.

DIAS, L. R. No fio do horizonte: educadoras da primeira infância e o combate ao racismo. 2012. $321 \mathrm{f}$. Tese (Doutorado) - Curso de Educação, Universidade de São Paulo, São Paulo, 2012.

FANON, F. Pele negra, máscaras brancas. Salvador: EDUFBA, 2008.

FARIA, A. L. G. de. A Contribuição dos Parques Infantis de Mario de Andrade para a

Construção de uma Pedagogia da Educação Infantil. Educação e Sociedade, Campinas, v. 20, n. 69, p. 60-91, dez. 1999.

Políticas de regulação, pesquisa e pedagogia na educação infantil, primeira etapa da educação básica. Educação e Sociedade, Campinas, (especial), v. 26, n. 92, p. 1013-1038, out. 2005.

. Para uma pedagogia da infância. Pátio: educação infantil, Porto Alegre, Artmed, v. 5, n. 14, p. 6-9, out. 2007.

FERNANDES, F. Sociedade de classes e subdesenvolvimento. Rio de Janeiro: Zahar, 1972.

(1943). As trocinhas do Bom Retiro. In: Folclore e mudança social na cidade de

São Paulo. São Paulo: Martins Fontes, 2004, p. 203-315.

FERNANDES, F.; BASTIDE, R. Brancos e negros em São Paulo. São Paulo: Global, 2008.

FONSECA, C. Quando cada caso NÃO é um caso: pesquisa etnográfica e educação. Revista Brasileira de Educação, Rio de Janeiro, 1999, n. 10, p. 58-78.

FOUCAULT, M.. Microfísica do Poder. Rio de Janeiro: Edições Graal, 1990.

História da sexualidade 1: a vontade de saber. Rio de Janeiro: Graal, 1999.

- Ditos e escritos. Estética: literatura e pintura, música e cinema. Organização e seleção de textos Manoel Barros da Motta. v. 3 Rio de Janeiro: Forense Universitária, 2001.

Estratégia, poder-saber. Rio de Janeiro: Forense Universitária, 2003.

Segurança, território e população. São Paulo: Martins Fontes, 2008.

GALLO, S. Em torno de uma educação voltada à singularidade: entre Nietzsche e Deleuze. In: LINS, D. (Org.). Nietz̧sche e Deleuð̨e: imagem, literatura e educação. Rio de Janeiro: Forense Universitária, 2007, v. 1, p. 288-302.

Infância e poder: algumas interrogações à escola. In: KOHAN, W. O. (org.). Devircriança da filosofia: infância da educação. Belo Horizonte: Autêntica, 2010, p. 109- 123.

GOMBROWICZ, W. Da maioridade à minoridade: filosofia, experiência e afirmação da infância. In: KOHAN, W. O. Infância: entre educação e filosofia. Belo Horizonte: Autêntica, 2005, p. 237-254.

GOMES, N. L. Sem perder a raiz: corpo e cabelo como símbolo da identidade negra. Belo Horizonte: Autêntica, 2008.

IANNI, Otavio. Dialética e capitalismo: ensaio sobre o pensamento de Marx. Petrópolis: Vozes, 1988.

MISKOLCI, R. Um corpo estranho na sala de aula. In: ABRAMOWICZ, A.; SILVÉRIO, V. R. Afirmando Diferenças. Campinas: Papirus, 2005, p. 13-25.

NASCIMENTO, M.. L. B. P. Reconhecimento da sociologia da infância como área de conhecimento e campo de pesquisa: algumas considerações. In: FARIA, A. L. G.; FINCO, D. (Orgs.). Sociologia da Infância no Brasil. Campinas: Autores Associados, 2011, p. 37-54.

NEGRI, Antônio. Cinco lições sobre Império. Rio de Janeiro: DP\&A, 2003. 
NIETZSCHE, Friedrich. Assim falou Zaratustra: um livro para todos e para ninguém. Rio de Janeiro: Civilização brasileira, 2003.

NOAL, M. L. Crianças pequenas indígenas: brincadeiras que são gritos. In: NOGUEIRA, A. L. H. (Org.) Ler e escrever na infância: imaginação, linguagem e práticas culturais. Campinas: Leitura Crítica, 2013, p. 59-78.

OLIVEIRA. F. Um estudo sobre a creche: o que as práticas educativas produzem e revelam sobre a questão racial? 2004. 112 f. Dissertação. (Mestrado em Educação) - Centro de Ciências Humanas, Universidade Federal de São Carlos, São Carlos. 2004.

OLIVEIRA, R. Relações raciais na escola: uma experiência de intervenção. 1992. 138 f. Dissertação (Mestrado). Faculdade de Educação, Pontifícia Universidade Católica, São Paulo, 1992.

PRADO, P. D. Educação e cultura infantil em creche: um estudo sobre as brincadeiras de crianças pequenininhas em um CEMEI de Campinas/SP. 1998. 139 f. Dissertação (Mestrado em Educação) - Faculdade de Educação, Universidade Estadual de Campinas, São Paulo. 1998.

As crianças pequenininhas produzem cultura? Considerações sobre educação e cultura infantil em creche. Pro-Posições, Campinas, UNICAMP, v. 10, p. 110-118, 1999.

ROSA, C. V. Creche de empresa privada: um estudo exploratório. 2009. 102 f. Dissertação (Mestrado em Educação). Faculdade de Educação. Universidade Estadual de Campinas, Campinas, 2009.

ROSEMBERG, F. Discriminações étnico-raciais na literatura infanto-juvenil brasileira. Tempo Brasileiro, São Paulo, n. 63, p. 21-39, 1980.

SCHERER, R. Charles Fourier e a infância para além das crianças. Belo Horizonte: Autêntica Editora, 2009.

SILVÉRIO, V. R. et al. Relações Étnico-Raciais. In: MISKOLCI, R. (Org.). Marcas da diferença no ensino escolar. São Carlos: EDUFSCar, 2010, p. 113-156.

SOUZA, Y. C. Crianças negras: deixei meu coração embaixo da carteira. Porto Alegre: Mediação, 2002.

TRINIDAD, C. T. Identificaşão étnico-racial na voz de crianşas em espaços de educação infantil. 2011. 222 f. Tese (Doutorado em Psicologia). Pontifícia Universidade Católica de São Paulo, São Paulo, 2011.

VELHO, G. Observando o familiar. In: NUNES, E. A aventura sociologica. Rio de Janeiro: Jorge Zahar, 1978, p. 36-46.

VILELA, E. Resistência e acontecimento. As palavras sem centro. In: KOHAN, W. O. Foucault 80 anos. Belo Horizonte: Autêntica, 2006, p.107-128.

\section{NOTAS}

${ }^{1}$ Essa designação foi inicialmente utilizada por Patrícia Dias Prado (1998) que traduziu a palavra italiana "picolissimi", ou os "muito pequenos", e refere-se às crianças na idade de 0 a 3 anos completos. O objetivo principal dessa denominação, segundo Prado (1998), resulta da necessidade emergente de se produzir novos conhecimentos relativos dentro das ciências sociais sobre a criança pequena brasileira, tanto mais, sobre as muito pequenas, que não conhecemos, senão pela Medicina e pela Psicologia.

${ }^{2} \mathrm{O}$ adultocentrismo é um dos colonialismos mais naturalizados pela sociedade contemporânea. Essa percepção colonial olha para a infância como se procurasse um outro adulto, o adulto que 
a criança será. "A biologização e naturalização da criança e do bebê, com os padrões adultos e de maturidade permeando a compreensão do desenvolvimento, retiram da infância a sua historicidade e seu potencial transformador" (ROSEMBERG, 1976, p. 17-18).

${ }^{3}$ Conjunto de valores culturais do mundo negro, tal como se exprime na vida, nas instituições e nas obras dos Negros (BASTIDE; FERNANDES, 1959).

${ }^{4}$ Os nomes das crianças pequenininhas negras são fictícios, mas com a característica de serem de origem africana; a opção por nomes de origem africana se estabeleceu com o intuito de fazer uma homenagem à cultura da África. A escolha dos nomes pode levar a percepção de uma dicotomização entre brancos e não brancos, no entanto, nesta pesquisa, trata-se de uma homenagem à cultura africana. Cada nome das crianças negras também foi pensado com relação ao significado etnológico do mesmo e a cena descrita.

${ }^{5}$ A história contada pela docente foi O Sonho de Rapunzel. Durante essa atividade as crianças ficaram impressionadas com os longos cabelos lisos e loiros da protagonista e destacaram principalmente as diferenças deste cabelo para com o da bruxa, que eram pretos, enrolados e com volume.

${ }^{6}$ Parto do princípio político que independente do sujeito possuir formação ou não em nível superior ele exercem a função docente na educação infantil.

Recebido: 31/03/2014

Aprovado: 24/10/2014

Contato:

Universidade Zumbi dos Palmares Av. Santos Dumont, 843 - Ponte Pequena

São Paulo $\mid$ SP $\mid$ Brasil

CEP 01.101-080 
